\author{
N. V. Medvedovska1,6, O. G. Shekera2,6, L. I. Denisyuk³, Ye. M. Anisimov', \\ N. M. Yanovskaya ${ }^{5}$ \\ ${ }^{1}$ National Academy of Medical Sciences of Ukraine, Kyiv, Ukraine \\ ${ }^{2}$ Shupyk National Healthcare University of Ukraine, Kyiv, Ukraine \\ ${ }^{3}$ Kyiv City Clinical Ophthalmological Hospital "Eye Microsurgery Center», Kyiv, Ukraine \\ ${ }^{4}$ Bogomolets National Medical University, Kyiv, Ukraine \\ 5 International Innovation Center of Human Harmonious Development, Kyiv, Ukraine \\ 'International Public Organization «International Association «Health of Society», Kyiv, Ukraine
}

\title{
THE RESULTS OF TEACHERS' AWARENESS ABOUT VISUAL IMPAIRMENT PREVENTION AMONG SCHOOL-AGE CHILDREN STUDY
}

\begin{abstract}
Background. According to the Center for Medical Statistics of the Ministry of Health of Ukraine, the number of children with ophthalmic diseases has increased significantly over the last decade. The purpose of the study was to determine the awareness of teachers of secondary schools (schools, lyceums) on the problem of visual impairment among schoolchildren with the identification of their willingness to participate in preventive measures. Materials and methods. The materials of the study were the results of a sociological survey of teachers of schools and lyceums in Ukraine (a total of 6215 questionnaires were subject to analysis). We used the method of sociological research and methods of medical statistics, in particular to calculate the representativeness and reliability of the survey results. The study complied with modern European requirements for anonymity; each of the respondents was involved in the survey only after prior oral voluntary consent. The results revealed a lack of awareness of teachers in the prevention of visual impairment among schoolchildren, their willingness to participate in prevention activities and the high need for information support for modern prevention technologies. The majority of respondents supported the need to introduce regular vision testing in childhood, including in the framework of the relevant state prevention program. Conclusions. The majority of teachers (99.40 $\pm 0.10 \%$ ) supporting the expediency of introducing regular vision testing in children, $(97.38 \pm 0.20 \%)$ support the introduction of a state prevention program to preserve vision from childhood. Based on the results of the study, promising for further research is the study of the possibility of involving teachers in preventive measures and participation in comprehensive programs for the prevention of ophthalmic pathology among students. It is also important to find effective ways of information support for educators on modern prevention technologies, risk factors for the formation of visual impairments in schoolchildren in order to prevent the formation of stigma against children with visual impairments and disorders in their environment.
\end{abstract}

Keywords: high school teachers; visual impairment; school-age children

\section{Introduction}

Visual functions play an extremely important role in a child's life and growth. The education of children in school at the age of 6-7 years is accompanied by a sharp increase in visual load, especially when the child begins secondary education, because it becomes necessary to learn to read and write.

Visual load is also excessive, because modern children from an early age master the computer, phone, tablet, and can work with them for hours.
The child's eyes are extremely sensitive to the mode and duration of visual load, especially at close range. The beginning of classes at school becomes a period of testing for the functions of the visual analyzer, and therefore, it exacerbates the problem of preventive support, timely detection of risk factors, prerequisites for the formation of ophthalmic pathology and, if necessary, medical intervention in case of disease.

According to the Center for Medical Statistics of the Ministry of Health of Ukraine, the number of children with

(С) «Здоров'я суспільства» / «Здоровье общества» / «Health of Society» ("Zdorov'a suspil'stva»), 2021

( ) Видавці Міжнародна громадська організація «Міжнародна асоціація «Здоров'я суспільства», Заславський 0.Ю. / Издатели Международная общественная организация «Международная ассоциация «Здоровье общества», Заславский А.Ю. / Publishers International Public Organization "International Association "Health of Society", Zaslavsky 0.Yu., 2021

Для кореспонденції: Медведовська Наталія Володимирівна, Національна академія медичних наук України, вул. Герцена, 12, м. Київ, 04050, Україна; e-mail: medvedovsky@ukr.net For correspondence: Nataliia Medvedovska, National Academy of Medical Sciences of Ukraine, Herzen str., 12, Kyiv, 04050, Ukraine; e-mail: medvedovsky@ukr.net 
ophthalmic diseases has increased significantly over the last decade. The identified domestic trends resonate with published WHO data and forecasts, which show that more than 1.7 million blind children are diagnosed in the world, while about 12 million children under the age of 15 suffer from visual impairment. Numerous studies provide examples of increasing the incidence of visual impairment in schoolchildren, among whom every tenth $(8-10 \%)$ in primary school has been diagnosed with ophthalmic pathology. Among high school students, this figure can rise to $30 \%$ [1-5].

The above actualizes the search for ways to prevent the occurrence of visual impairments among school-age children, strengthening the preventive vector, compliance with the rules of visual hygiene of schoolchildren, which makes this problem not only medical.

Educators who are in daily contact with school-age children have the opportunity to actively participate in the educational process.

The purpose of our study was to study the attitude of teachers and teachers of secondary schools (schools, lyceums) to the prevention of visual impairments among students, shifting their willingness to participate in joint preventive activities with physicians.

\section{Materials and methods}

The materials of the study were the results of a sociological survey conducted among educators of secondary schools in Ukraine (teachers, school and lyceum teachers) (a total of 6215 questionnaires were subject to analysis). To perform the objectives of the study and achieve the stated goal, we used the method of sociological research and methods of medical statistics, in particular to calculate the representativeness and reliability of the survey results. The study complied with modern European requirements for anonymity; each of the respondents was involved in the survey only after prior oral voluntary consent.

The survey, which was preceded by a pilot study (50 questionnaires), involved a total of 6,350 respondents, although 135 questionnaires $(2.12 \%)$ were rejected during the analysis and entry of the survey results into the electronic database, so the results of the survey were further analyzed. 6,215 questionnaires.

\section{Results and discussion}

Most of the surveyed teachers were female $(92.71 \pm 0.33 \%)$ in the main working age $25-54$ years $(78.66 \pm 0.52 \%)$ and had higher pedagogical education $(95.11 \pm 0.27 \%)$. More than half of the respondents had a long experience of educational work, every fourth $(25.68 \pm 0.55 \%)$ worked as a teacher from 26-35 years, another $24.55 \pm 0.55 \%$ had a work experience of $16-25$ years. Only $7.84 \pm 0.34 \%$ of respondents said that visual impairment in children and knowledge of their first signs is a purely medical problem. Instead, $90.46 \pm 0.37 \%$ of respondents believe that a high school employee should have knowledge of the early signs of visual impairment in schoolchildren.

Most teachers $(86.39 \pm 0.43 \%)$ are familiar with the hygienic norms of visual load in childhood, and therefore consciously prefer and encourage students to play actively in the fresh air $(94.16 \pm 0.30 \%)$.
In most schools/lyceums whose teachers have agreed to become respondents to the survey, the school employs a nurse, who is responsible for, among other things, preventive work to prevent visual impairment among students. At the same time, almost every fifth $(17.84 \pm 0.49 \%)$ school does not have such medical staff.

More than a third $(39.52 \pm 0.62 \%)$ of the surveyed educators of secondary educational institutions expressed the opinion that even in the presence of physicians in the educational institution, preventive educational work to preserve vision from childhood is insufficient, another 5.70 $\pm 0.29 \%$ respondents expressed a categorical negative assessment of such preventive work at school, explaining it by the lack of medical staff in the school, whose responsibilities include this area of work.

At the same time, almost half of the surveyed teachers $(54.79 \pm 0.63 \%)$ consider the amount of preventive work carried out by medical staff at the school / lyceum sufficient.

Positively, almost all $(94.92 \pm 0.28 \%)$ educators of schools and lyceums consider it their duty to inform children about the risk of eye diseases and injuries and only $13.37 \pm 0.43 \%$ are not familiar with the hygienic norms of visual load. in childhood, and therefore due to ignorance they are not followed.

The most common eye diseases in childhood according to secondary school teachers are: refractive errors, such as myopia $(75.74 \pm 0.54 \%)$, astigmatism $(35.72 \pm 0.61 \%)$ and farsightedness ( $70 \pm 0.63 \%)$; conjunctivitis $(68.19 \pm 0.59 \%)$; strabismus (66.32 $\pm 0.60 \%)$; barley $(57.01 \pm 0.63 \%)$; eye injuries $(55.40 \pm 0.63 \%)$.

Most teachers allow the possibility of the impact of poor eyesight on the appearance of headaches, especially with prolonged visual load $(94.59 \pm 0.29 \%)$; the appearance of the habit of moving closer (to approach) to see the details of the image (object) $(92.24 \pm 0.34 \%)$; reduction of student performance due to the impossibility of clear copying from the board $(78.95 \pm 0.52 \%)$. Manifestations of visual impairment in schoolchildren can be: slow reading and writing (72.07 $\pm 0.57 \%)$; slowing of letter recognition, uncertainty of movements when drawing $(71.30 \pm 0.57 \%)$; the appearance of the habit of rubbing the eyes with the hands (69.69 $\pm 0.58 \%)$ and "crouching" when drawing (writing) with the appearance of distortion or violation of posture (69.44 $\pm 0.58 \%)$.

According to educators, vision problems in children of school age in most cases $(91.63 \pm 0.35 \%)$ are caused by burdened heredity, while $8.37 \pm 0.35 \%$ believe that heredity has no decisive influence on the occurrence of ophthalmic pathology. More than half $(58.25 \pm 0.63 \%)$ of respondents believe that the child's vision is influenced by the nature of nutrition, while $41.75 \pm 0.63 \%$ believe that such an effect is absent.

Almost all $(97.80 \pm 0.19 \%)$ are informed that insufficient lighting at close range is a risk for the formation of eye pathology in childhood.

When asked whether children with vision problems are prone to solitude, one third of secondary school teachers $(37.41 \pm 0.61 \%)$ confirmed that they had encountered this, although more than half $(58.50 \pm 0.63 \%)$ ) respondents, never noticed this. 
At the same time, almost half of teachers $(43.17 \pm 0.63 \%)$ noticed how children "tease" and insult their peers who have visual impairments (for example, wearing glasses). At the same time, almost all teachers $(95.98 \pm 0.25 \%)$ deny the idea that children with visual impairments should grow and study separately from peers, as they consider it inappropriate.

The vast majority of educators $(96.35 \pm 0.24 \%)$ in case of detection of ophthalmic pathology would entrust the supervision of the formation of vision in a child to a pediatric ophthalmologist.

The results of the sociological study revealed that $71.70 \pm 0.57 \%$ of high school teachers need information support on the prevention of risk factors, detection of signs and symptoms of ophthalmic pathology among schoolage children. Sources of information preferred by teachers were also identified, among them: Internet $(74.18 \pm 0.56 \%)$ and periodicals $(38.92 \pm 0.62 \%)$; informing medical staff, in particular receiving information from family doctors ( $52.74 \pm 0.63 \%)$, other doctors $35.21 \pm 0.61 \%$.

Almost all $(99.4 \pm 0.10 \%)$ teachers support the idea of the need for regular vision testing in childhood. Also, the majority $(97.38 \pm 0.20 \%)$ of respondents support the need to introduce a state prevention program to preserve vision from childhood in Ukraine.

\section{Conclusions}

The results of the survey of secondary school teachers revealed their lack of awareness of the prevention of visual impairment among students, insufficient level of preventive work of medical staff in schools combined with the willingness of educators to participate in preventive measures ( $86.39 \pm 0.43 \%$ are familiar with hygiene). norms of visual load in childhood, $94.92 \pm 0.28 \%$ inform children about the risk of diseases and injuries of the eye, $94.16 \pm 0.30 \%$ encourage children to play actively in the fresh air). The majority of teachers $(99.40 \pm 0.10 \%)$ supporting the expediency of introducing regular vision testing in children, $97.38 \pm 0.20 \%$ support the introduction of a state prevention program to preserve vision from childhood.

Prospects of further research. Based on the results of the study, promising for further research is the study of the possibility of involving teachers in preventive measures and participation in comprehensive programs for the prevention of ophthalmic pathology among students. It is also important to find effective ways of information support for educators on modern prevention technologies, risk factors for the formation of visual impairments in schoolchildren in order to prevent the formation of stigma against children with visual impairments and disorders in their environment.

Conflict of interest. The authors declare no conflict of interest in the preparation of this article.

\section{References}

1. Медико-соціальний моніторинг стану зору та факторів ризику його порушень у школярів : метод. Рекомендації / уклад.: С. О. Риков, Н. М. Орлова, А. О. Костецька; Нац. мед. акад. післядиплом. освіти ім. П.Л. Шупика, Укр. Центр наук. мед. інформації та патент.-ліценз. роботи. - K., 2013. -20 c.

2. Орлова Н. М. Стан офтальмологічного здоров'я школярів та організаційна технологія його медико-соціального моніторингу / Н. М. Орлова, А. О. Костецька // Україна. Здоров'я нації. - 2014. - № 1. - С. 7-12.

3. Офтальмологічна допомога в Україні за 2006-2011 роки: (аналіт.-статист. довідник) / розроб.: Ю. В. Баринов, Т. А. Аліфанова, Н. А. Обухова, Л. В. Венгер, А. С. Гудзь, О. П. Вітовська, І. В. Шаргородська, О. М. Черемухіна, В. І. Шевченко, А. О. Костецька, Н. Г. Руденко, Г. Л. Степанюк, Г. В. Шиак, К. В. Коробов, Н. В. Некрасова. K., 2012. $-183 c$.

4. Сліпота та слабкозорість. Шляхи профілактики в Україні. С. О. Риков, О.П. Вітовська, Н. А. Обухова, С. А. Сук, I. В. Шаргородська. Навчальний посібник // За редакцію проф. Рикова С. О. - К.: ТОВ «Доктор-Медіа». 2012. $-164 c$.

5. Риков С. О., Медведовська Н. В., Збітнева С. В. Моніторинг регіональних особливостей поширеності хвороб ока та придаткового апарату серед населення України // Східноєвроп. Журн. Громад. Здоров'я. - 2012. - Спец. Bun. - C. 95-96.

Медведовська Н. В. 1.6, Шекера О. Г. ${ }^{2,6}$, Аенисюк А. І. ${ }^{3}$, Анісімов Є. М.4, Яновська Н. M. ${ }^{5}$

${ }^{1}$ Національна акалемія медичних наук України, м. Київ, Україна

${ }^{2}$ Національний університет охорони зАоров'я України імені П. А. Шупика, м. Київ, Україна

${ }^{3}$ Київська міська клінічна офтальмологічна лікарня “Центр мікрохірургії ока», м. Київ, Україна

${ }^{4}$ Національний меАичний університет імені О. О. Богомольця, м. Київ, Україна

${ }^{5}$ Міжнародний інноваційний центр гармонійного розвитку ююАини, м. Київ, Україна

'Міжнародна громадська організація "Міжнародна асоціація «ЗАоров'я суспільства», м. Київ, Україна

\section{РЕЗУАЬТАТИ АОСАІАЖЕННЯ ОБІЗНАНОСТІ ВЧИТЕАІВ ПРО ПРОФІААКТИКУ ПОРУШЕНЬ ЗОРУ У АІТЕЙ ШКіАЬНОГО ВіКУ}

Резюме. Актуальність. За даними Центру медичної статистики Міністерства охорони здоров'я України, кількість дітей з офтальмологічними захворюваннями за останнє десятиліття значно збільшилася. Метою дослідження стало визначення обізнаності вчителів загальноосвітніх навчальних закладів (школи, ліцеї) з проблем порушення зорових функцій серед школярів з виявленням їх готовності взяти участь в профілактичних заходах. Матеріали та методи. Матеріалами дослідження були результати соціологічного опитування вчителів шкіл та ліцеїв України. Всього проаналізовано 6215 анкет. Використано методи соціологічного дослідження і медичної статистики, у тому числі, для розрахунку репрезентативності 
та достовірності результатів опитування. Дослідження відповідало сучасним європейським вимогам до анонімності; кожен з респондентів брав участь в опитуванні тільки після попередньої усної добровільної згоди. Результати. Виявилено недостатню поінформованість педагогів у питаннях попередження порушень зорових функцій серед школярів, при їх готовності взяти участь у профілактичних заходах і високу потребу в інформаційній підтримці щодо сучасних профілактичних технологій. Більшість опитаних підтримали думку про доцільність впровадження регулярної перевірки зору в дитячому віці, у тому числі, у рамках відповідної державної профілактичної

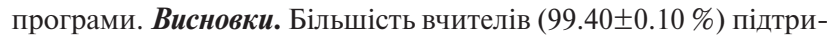

мують доцільність введення регулярної перевірки зору у дітей, $97.38 \pm 0.20 \%$ підтримують введення державної профілактичної програми по збереженню зору з дитинства. За результатами дослідження, перспективним для подальших досліджень $€$ вивчення можливості залучення вчителів до профілактичних заходів і до участі в комплексних програмах профілактики офтальмопатології серед учнів. Також важливо знайти ефективні способи інформаційної підтримки вчителів з приводу сучасних профілактичних технологій, факторів ризику формування порушень зору у школярів.

Ключові слова: вчителі середньої школи; порушення зорових функцій; діти шкільного віку

Медведовская Н. В. 1.6, Шекера О. Г.2., Аенисюк А. И. ${ }^{3}$, Анисимов Е. Н.4, Яновская Н. Н. ${ }^{5}$

${ }^{1}$ Национальная академия медицинских наук Украины, г. Киев, Украина

${ }^{2}$ Национальный университет заравоохранения Украины имени П. А. Шупика, г. Киев, Украина

${ }^{3}$ Киевская городская клиническая офтальмологическая больница «Центр микрохирургии глаза», г. Киев, Украина

${ }^{4}$ Национальный медицинский университет имени А. А. Богомольца, г. Киев, Украина

${ }^{5}$ МежАународный инновационный центр гармоничного развития человека, г. Киев, Украина

' Межаународная общественная организация «Межаународная ассоциация «ЗАоровье общества», г. Киев, УКраина

\section{РЕЗУАЬТАТЫ ИССАЕАОВАНИЯ ОСВЕАОМАЕННОСТИ УЧИТЕАЕЙ О ПРОФИААКТИКЕ НАРУШЕНИЙ ЗРЕНИЯ У АЕТЕЙ ШКОАЬНОГО ВОЗРАСТА}

Резюме. Актуальность. По данным Центра медицинской статистики Министерства здравоохранения Украины, количество детей с офтальмологическими заболеваниями за последнее десятилетие значительно увеличилось. Целью исследования стало определение осведомленности учителей общеобразовательных учебных заведений (школы, лицеи) по проблеме нарушения зрительных функций среди школьников с выявлением их готовности принять участие в профилактических мероприятиях. Материалы и методы. Материалами исследования были результаты социологического опроса учителей школ и лицеев Украины. Всего проанализировано 6215 анкет. Использованы методы социологического исследования и медицинской статистики, в часности для расчета репрезентативности и достоверности результатов опроса. Исследование соответствовало современным европейским требованиям к анонимности; каждый из респондентов участвовал в опросе только после предварительного устного добровольного согласия. Результаты. Выявлена недостаточная осведомленность педагогов в вопросах предупреждения нарушений зрительных функций среди школьников, при их готовности принять уча- стие в профилактических мероприятиях и высокой потребности в информационной поддержке касательно современных профилактических технологий. Большинство опрошенных поддержали мнение о целесообразности внедрения регулярной проверки зрения в детском возрасте, в том числе в рамках соответствующей государственной профилактической программы. Bыводы. Большинство учителей $(99.40 \pm 0.10 \%)$ поддерживают целесообразность введения регулярной проверки зрения у детей, $97.38 \pm 0.20 \%$ поддерживают введение государственной профилактической программы по сохранению зрения с детства. По результатам исследования, перспективным для дальнейших исследований является изучение возможности привлечения учителей к профилактическим мероприятиям и к участию в комплексных программах профилактики офтальмопатологии среди учеников. Также важно найти эффективные способы информационной поддержки учителей по поводу современных профилактических технологий, факторов риска формирования нарушений зрения у школьников.

Ключевые слова: учителя средней школы; нарушение зрительных функций; дети школьного возраста 